\title{
Characterization of Local Structures of Confined Imidazolium Ionic Liquids in PVdF-co-HFP Matrices by High Pressure Infrared Spectroscopy
}

\author{
Teng-Hui Wang, Ming-Siou Wu and Hai-Chou Chang *D \\ Department of Chemistry, National Dong Hwa University, Shoufeng, Hualien 974, Taiwan; \\ 810712101@gms.ndhu.edu.tw (T.-H.W.); 610712011@gms.ndhu.edu.tw (M.-S.W.) \\ * Correspondence: hcchang@gms.ndhu.edu.tw; Tel.: +886-3-8903585
}

Received: 17 August 2020; Accepted: 30 September 2020; Published: 5 October 2020

check for updates

\begin{abstract}
The nanoscale ion ordering of ionic liquids at confined interfaces under high pressures was investigated in this study. 1-Hexyl-3-methylimidazolium bis(trifluoromethylsulfonyl)imide ([HMIM][NTf 2$]$ )/poly(vinylidene fluoride-co-hexafluoropropylene) (PVdF-co-HFP) and 1-ethyl-3methylimidazolium bis(trifluoromethylsulfonyl)imide ([EMIM][NTf $\left.\left.{ }_{2}\right]\right) / \mathrm{PVdF}-\mathrm{co}-\mathrm{HFP}$ were prepared and characterized by using high-pressure infrared spectroscopy. Under ambient pressure, imidazolium $\mathrm{C}^{2}-\mathrm{H}$ and $\mathrm{C}^{4,5}-\mathrm{H}$ absorptions were blue-shifted in frequency due to the presence of PVdF-co-HFP. However, the absorption of anionic $v_{\mathrm{a}} \mathrm{SO}_{2}$ did not reveal any significant shifts in frequency upon dilution by PVdF-co-HFP. The experimental results suggest that PVdF-co-HFP disturbs the local structures of the imidazolium $\mathrm{C}-\mathrm{H}$ groups instead of the anionic $\mathrm{SO}_{2}$ groups. The frequency shifts of $\mathrm{C}^{4,5}-\mathrm{H}$ became dramatic for the mixtures at high pressures. These results suggest that pressure-enhanced ionic liquid-polymer interactions may play an appreciable role in IL-PVdF-co-HFP systems under high pressures. The pressure-induced blue-shifts due to the PVdF-co-HFP additions were more obvious for the $[\mathrm{HMIM}]\left[\mathrm{NTf}_{2}\right]$ mixtures than for $[\mathrm{EMIM}]\left[\mathrm{NTf}_{2}\right]$ mixtures.
\end{abstract}

Keywords: poly(vinylidene fluoride-co-hexafluoropropylene) (PVdF-co-HFP); high-pressure; infrared spectroscopy; ionic liquids (ILs)

\section{Introduction}

The high safety requirements of lithium-ion batteries in mobile devices such as smartphones and other flexible electronic devices such as smartphones and other flexible electronic devices have necessitated the development of noncombustible gel-like electrolytes [1-4]. Polymer electrolytes, comprising a combination of flexible semi-crystalline polymer matrices and electrolytes, can separate the cathode and anode in a battery, avoid short circuits, and maintain high ion conductivity. Poly(vinylidene fluoride-co-hexafluoropropylene) (PVdF-co-HFP) containing vinylidene fluoride (VdF) and hexafluoropropylene (HFP) moieties is a potential candidate for the matrix in polymer electrolytes [4-9]. The incorporation of the HFP unit in PVdF-co-HFP may increase the flexibility of the polymer due to the presence of low crystalline structures in the copolymers [5,8-11]. Researchers have shown that the low crystallinity of PVdF-co-HFP compared to the unmodified PVdF leads to a higher ionic conductivity in PVdF-co-HFP-based polymer electrolytes $[5-8,10]$. The crystalline phase of the polymers limits the migration of ions in Li-ion batteries. Flexibility of the polymers can be easily changed by adding plasticizers such as nanoparticles and ionic liquids (ILs) [1,5]. Researchers have discovered that PVdF-co-HFP and its mixtures hold promising applications as precursors of gas sensors [12] and can also be used in Li-ion batteries [1,4], dye-sensitized solar cells [13], and supercapacitors [2,6].

Based on the versatility of ionic liquids (ILs), there is the possibility of obtaining ILs with high ionic conductivities, large electrochemical windows, great thermal stability, gas adsorption, 
non-flammability, and low toxicity [14-18]. Some researchers have suggested that heterocyclic-based ILs such as alkyl-methyl-imidazolium ILs, are possible choices for polymer electrolytes due to the ease with which their physical properties can be modified $[7,19]$. However, the applications of imidazolium-based ILs in Li-ion systems are limited due to the reactivity of imidazolium $\mathrm{C}^{2}-\mathrm{H}$ (C-H at the $\mathrm{C}^{2}$ position of imidazolium cation). Due to their asymmetry, modifiable alkyl length, and the delocalized charge on the cation, the imidazolium cations and anions of the ILs may heterogeneously aggregate into nanostructures [20,21]. In other words, the cations and anions in the IL may associate together into clusters, resulting in the formation of quasi-crystal-like structures [20-22]. Additionally, previous studies have suggested that varying the alkyl chain length of the cations may affect the interactions between the IL ions, which can lead to changes in the associated structures $[7,19,20]$. There exists a debate about the interpretation of the IR spectra of 1-ethyl-3-methylimidazolium bis(trifluoromethylsulfonyl)imide ([EMIM][NTf $\left.\left.f_{2}\right]\right)$ in the region of imidazolium $\mathrm{C}-\mathrm{H}$ vibration [15]. The complicated $\mathrm{C}-\mathrm{H}$ spectra features of [EMIM][NTf ${ }_{2}$ ] may result from micro-heterogeneity and Fermi-resonance interactions. The cluster model and hydrogen-bonding structures may play non-negligible roles in the ILs with [NTf 2 ] anions [15].

Various studies on polymer electrolytes, comprising a polymer host and an IL guest, have revealed specific properties of ion migration in the polymers [1-3,5,6,13]. Additionally, it is important to understand the interactions between the polymer backbone and the IL ions in order to design suitable polymer electrolytes that can enhance their potential applications [2,3,23]. Liang et al. [24] concluded that the IL-polymer interactions mainly arise due to the associations between the positively charged ions (such as imidazolium, ammonium, and phosphonium) of the IL and the $\mathrm{CF}_{2}$ moiety in PVdF, rather than between the anions and polymer chains. In contrast, simulation studies have indicated that the hydrogen atoms of methylene groups present in the polymers (PVdF) are excellent nucleophilic sites and can interact with the anions ([BF4]) of ILs via electrostatic interactions. Natural bond orbital (NBO) [25] calculations suggest that the interaction energies between the ILs and PVdF do not depend on the alkyl chain length of the IL cation $\left(\left[\mathrm{C}_{n} \mathrm{MIM}\right]\right)$. Moreover, based on the results of the thermal

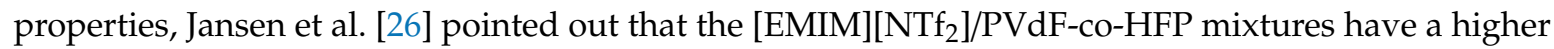
density than the linear interpolation of the value of the pure PVdF-co-HFP and pure [EMIM][NTf $f_{2}$. This indicates an efficient packing and a high affinity between [EMIM][NTf 2 ] and PVdF-co-HFP. The imidazolium-based ILs with [NTf2] anions and PVdF-co-HFP seem to have good compatibility to form blend membranes [7,26]. A thorough investigation of the interactions between polymers and IL ions (cations or anions) may provide information, which is pertinent to the future applications of polymer electrolytes. In this context, the precise mechanism of the interactions in polymer electrolytes is still a point of debate in the literature [24-26].

High-pressure infrared spectroscopy is a straightforward method to study the adjusted vibrational signals by forcing molecules to come close to each other. Modulating the molecular environments and non-covalent interactions by high pressures may provide special insights into the thermodynamically stable conformations of chemical systems [27-31]. This connotes that, under high-pressure conditions, the IL ions and the PVdF-co-HFP may aggregate at hydrostatic pressures. IR spectroscopy performed under high pressures may reveal whether it is the IL anions or the IL imidazolium cations that tend to associate with the polymers. In previous studies, IL cations have been known to form stable associations with deoxyribonucleic acid sodium salt (DNA) [27] under high pressures. Moreover, the results of previous studies imply that the IL hydrogen-bonding network or cluster structure may be disturbed on mixing additives such as porous silica [28], $\beta$-cyclodextrin [29], aluminum oxide [30], and mica [31] under high pressures.

\section{Materials and Methods}

The electrolyte samples were prepared using poly(vinylidene fluoride-co-hexafluoropropylene) (PVdF-co-HFP, average MW 455,000, Sigma-Aldrich, St. Louis, MO, USA), 1-hexyl-3-methylimidazolium bis (trifluoromethylsulfonyl) imide ([HMIM] $\left[\mathrm{NTf}_{2}\right], \geq 98 \%$, Sigma-Aldrich, St. Louis, MO, USA), 
1-ethyl-3-methylimidazolium bis (trifluoromethylsulfonyl) imide ([EMIM][NTf 2 ], 99\%, UniRegion Bio-Tech, Taoyuan, Taiwan), and N, N-dimethylformamide (DMF, $\geq 99.9 \%$, Sigma-Aldrich, St. Louis, $\mathrm{MO}, \mathrm{USA})$. The water contents of [HMIM][NTf $\left.{ }_{2}\right]$ and [EMIM][NTf $\left.{ }_{2}\right]$ were determined to be 1.5 and $1.0 \mathrm{wt} . \%$, respectively, by a moisture analyzer (MS-70, A\&D Company). [HMIM][NTf $\left.{ }_{2}\right] / \mathrm{PVdF}_{\mathrm{H}-\mathrm{Co}-\mathrm{HFP}}$ or [EMIM][NTf 2$] / P V d F-c o-H F P$ mixtures were prepared with 10, 20, 30, 40, and 50 weight percentages of the IL and suitable amounts of DMF as the solvent. The solutions were then stirred at $70{ }^{\circ} \mathrm{C}$ for $30 \mathrm{~min}$. The solvent (DMF) was removed under vacuum and the samples were kept in sunlight for at least one day. The mixtures were further dried at $155^{\circ} \mathrm{C}$ with a moisture analyzer before all the spectral measurements. The removal of DMF was confirmed by the disappearance of DMF absorptions in the IR spectra.

High pressure (up to $2 \mathrm{GPa}$ ) was generated using a diamond anvil cell (DAC) equipped with two type-IIa diamonds with a diamond culet size of $0.6 \mathrm{~mm}$. IR measurements were performed using a Fourier-transform (FT) spectrophotometer (Spectrum RXI, Perkin-Elmer, Naperville, IL) equipped with a lithium tantalite detector. A 5-beam condenser was combined with the IR spectrophotometer to enhance the intensity of the passed infrared beam. To eliminate the absorption of the diamond anvils, the absorption spectra of the DAC were measured and subtracted from those of the samples. A $0.25 \mathrm{~mm}$ thick Inconel gasket with a $0.3 \mathrm{~mm}$ diameter hole was prepared (using a mechanical drill) to serve as the sample holder. To reduce the absorbance of the samples, transparent $\mathrm{CaF}_{2}$ crystals were placed into the sample holder and compressed before inserting the samples. A resolution of $4 \mathrm{~cm}^{-1}$ (data point resolution of $2 \mathrm{~cm}^{-1}$ ) and 1000 scans were chosen for the high-pressure measurements. Pressure calibration was performed following Wong's method [32,33]. Spectral processing was performed with the software Origin. Gaussian or Lorentzian functions were applied for spectral deconvolution.

\section{Results and Discussion}

\subsection{Ambient Pressure IR Study of [HMIM][NTf 2$] / P V d F-c o-H E P$ System}

Figure 1 presents the IR spectra of (a) pure [HMIM][NTf $\left.f_{2}\right]$, (b) mixture of PVdF-co-HFP with $50 \mathrm{wt} . \%$ of [HMIM][NTf ${ }_{2}$, (c) mixture of PVdF-co-HFP with $10 \mathrm{wt} . \%$ of [HMIM][NTf ${ }_{2}$ ], and (d) pure PVdF-co-HFP, which were recorded in the region of $3400-2800 \mathrm{~cm}^{-1}$ under ambient pressure.

The IR spectrum of pure [HMIM] $\mathrm{NTf}_{2}$ ] contains vibrational absorptions at 2866, 2934, and $2959 \mathrm{~cm}^{-1}$ corresponding to the three alkyl C-H cations [27-31]. The IR spectrum of pure PVdF-co-HFP revealed two characteristic alkyl C-H peaks at 2979 and $3021 \mathrm{~cm}^{-1}$ [34]. The alkyl C-H peak of the cation at $2866 \mathrm{~cm}^{-1}$ in Figure 1a was very slightly shifted compared to the $2869 \mathrm{~cm}^{-1}$ peak obtained on mixing PVdF-co-HFP with the IL (Figure 1c). Nevertheless, the two other absorptions of the alkyl C-H cations at 2936 and $2962 \mathrm{~cm}^{-1}$, respectively, in Figure 1b,c overlap with the alkyl C-H peak of pure PVdF-co-HFP. The alkyl C-H absorption peak at $3018 \mathrm{~cm}^{-1}$ in the mixture of PVdF-co-HFP with $50 \mathrm{wt} . \%$ of [HMIM][NTf ${ }_{2}$ (Figure $1 \mathrm{~b}$ ) revealed a very small red shift compared to that of pure PVdF-co-HFP at $3021 \mathrm{~cm}^{-1}$ in Figure 1d. These observations imply that the alkyl C-H peaks of the cation and the polymer in the region between 2800 and $3075 \mathrm{~cm}^{-1}$ may not be sensitive enough to provide any valuable information. In the case of pure [HMIM][NTf $\left.f_{2}\right]$, the IR absorptions of the imidazolium C-H moieties are located at $3120 \mathrm{~cm}^{-1}$ (with a minor peak at $3100 \mathrm{~cm}^{-1}$ ) and $3157 \mathrm{~cm}^{-1}$, corresponding to the $\mathrm{C}^{2}-\mathrm{H}$ and $\mathrm{C}^{4,5}-\mathrm{H}$ absorptions. However, the peaks for the imidazolium $\mathrm{C}^{2}-\mathrm{H}$ and $\mathrm{C}^{4,5}-\mathrm{H}$ groups shifted to 3121 and $3163 \mathrm{~cm}^{-1}$, respectively (Figure 1c), in the presence of PVdF-co-HFP.

Figure 2 illustrates the IR spectra of (a) pure [HMIM] [NTf $\left.f_{2}\right]$, (b) mixture of PVdF-co-HFP with $50 \mathrm{wt} . \%$ of [HMIM][NTf 2 , (c) mixture of PVdF-co-HFP with $10 \mathrm{wt} . \%$ of [HMIM][NTf 2 , and (d) pure PVdF-co-HFP, which were recorded in the region of $800-1450 \mathrm{~cm}^{-1}$ under ambient pressure. 


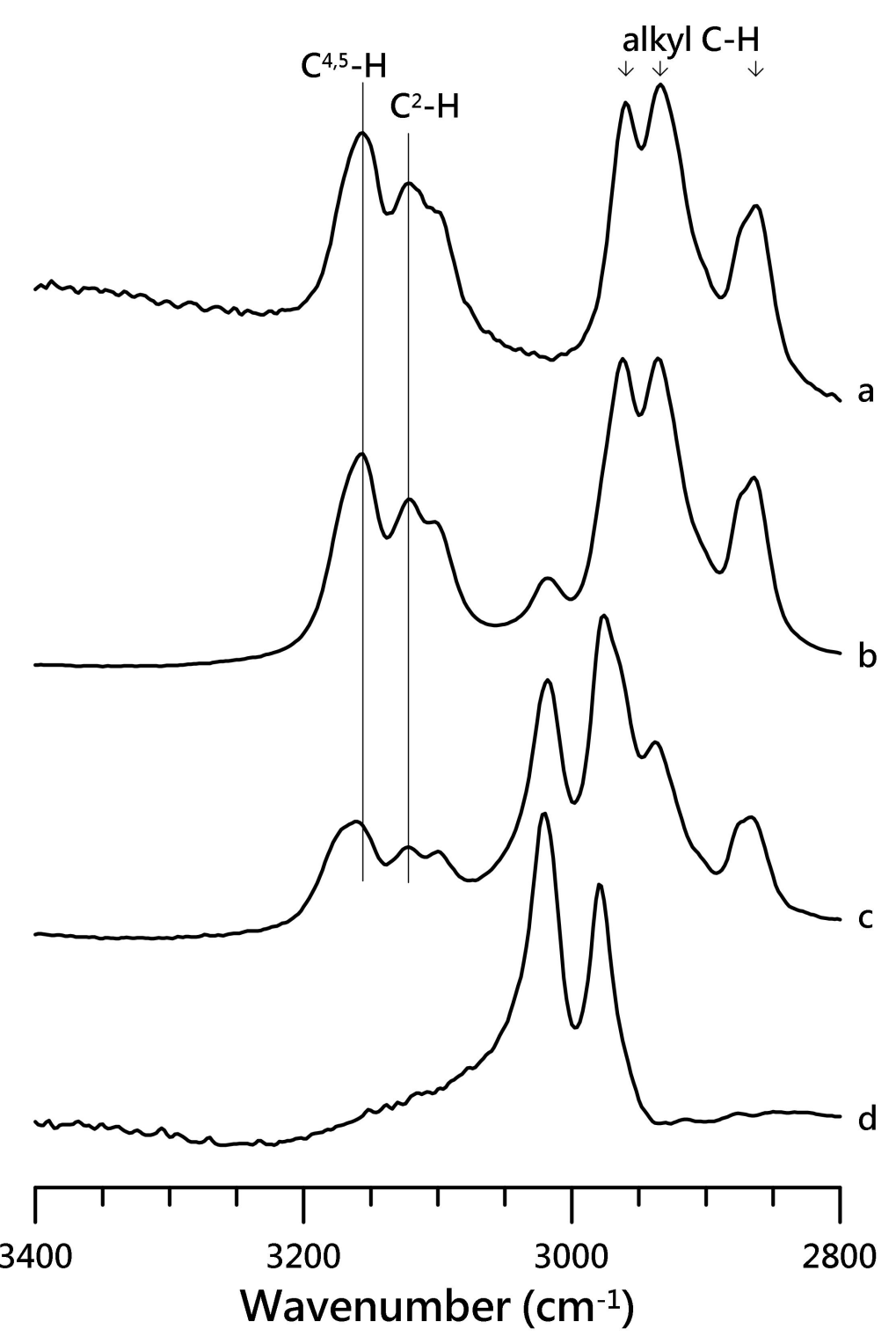

Figure 1. IR spectra of (a) pure [HMIM][NTf 2$]$, (b) mixture of PVdF-co-HFP with 50 wt.\% of [HMIM][NTf 2$]$, (c) mixture of PVdF-co-HFP with 10 wt.\% of [HMIM][NTf 2 , and (d) pure PVdF-co-HFP, recorded under ambient pressure.

Figure 2a revealed four major vibrational absorptions at $1058(v \mathrm{SNS}), 1140\left(v_{\mathrm{s}} \mathrm{SO}_{2}\right), 1196$ $\left(v \mathrm{CF}_{3}\right)$, and $1352\left(v_{\mathrm{a}} \mathrm{SO}_{2}\right) \mathrm{cm}^{-1}$, originating from the IL anion $\left(\left[\mathrm{NTf}_{2}\right]^{-}\right)[35,36]$. Pure PVdF-co-HFP showed several characteristic polymer absorptions at 839, 881, 1074, 1179, 1233, and $1404 \mathrm{~cm}^{-1}$ [34]. The vibrational absorptions at 1196 and $1226 \mathrm{~cm}^{-1}$ for the $\mathrm{CF}_{3}$ moiety in [NTf2] overlap significantly with the $\mathrm{CF}_{2}$ absorptions of PVdF-co-HFP at 1179 and $1233 \mathrm{~cm}^{-1}$ for the mixtures (Figure $2 \mathrm{~b}, \mathrm{c}$ ). Likewise, the spectral features of the IL anion at $1058 \mathrm{~cm}^{-1}(v \mathrm{SNS})$ are also affected by the polymer absorption at $1074 \mathrm{~cm}^{-1}$, as seen in Figure $2 b$,c. The absorptions of $v_{a} \mathrm{SO}_{2}$ at 1352 and 1334 (minor peak) cm ${ }^{-1}$ for pure [HMIM][NTf ${ }_{2}$ ] were slightly shifted to 1351 and $1333 \mathrm{~cm}^{-1}$ for the mixture of PVdF-co-HFP with $10 \mathrm{wt}$. $\%$ of [HMIM][NTf 2 ]. Similarly, the $v_{\mathrm{s}} \mathrm{SO}_{2}$ band minimally blue-shifted (within $1 \mathrm{~cm}^{-1}$ ) to $1141 \mathrm{~cm}^{-1}$ (Figure 2c). The characteristic absorptions of PVDF-co-HFP in the mixture with $50 \mathrm{wt} . \%$ of [HMIM] $\left[\mathrm{NTf}_{2}\right.$ ] revealed almost negligible shifts to 839,882 , and $1403 \mathrm{~cm}^{-1}$ in comparison to the pure PVDF-co-HFP. These experimental results suggest that anionic $\mathrm{SO}_{2}$ groups and polymers may not significantly disturb each other. However, the results in Figure 1 indicate that the presence of PVdF-co-HFP disturbs the local structures of the imidazolium C-H groups in the IL cations [2]. 


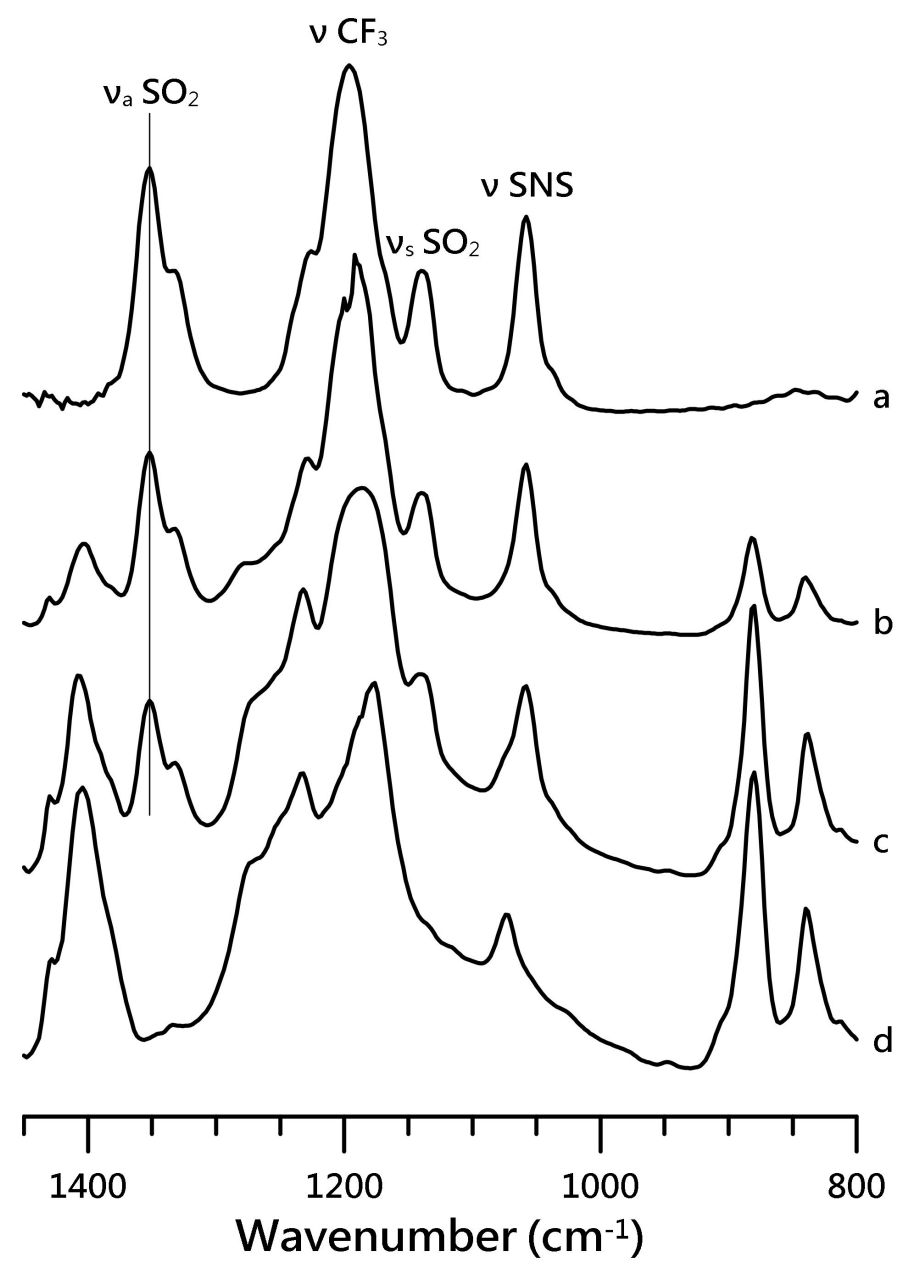

Figure 2. IR spectra of (a) pure [HMIM][NTf $\left.\mathrm{N}_{2}\right]$, (b) mixture of PVdF-co-HFP with 50 wt.\% of [HMIM][NTf 2 ], (c) mixture of PVdF-co-HFP with 10 wt.\% of [HMIM][NTf 2 , and (d) pure PVdF-co-HFP, recorded under ambient pressure.

Figure 3 depicts the concentration-dependence of (A) imidazolium $\mathrm{C}^{4,5}-\mathrm{H}$ and $\mathrm{C}^{2}-\mathrm{H}$, and (B) anionic $v_{\mathrm{a}} \mathrm{SO}_{2}$ stretching frequencies versus the wt.\% of [HMIM][NTf $\left.\mathrm{N}_{2}\right]$. The $\mathrm{C}^{4,5}-\mathrm{H}$ and $\mathrm{C}^{2}-\mathrm{H}$ absorption peaks of [HMIM] [NTf $\left.{ }_{2}\right]$ showed a small frequency-shift with high concentrations of $[\mathrm{HMIM}]\left[\mathrm{NTf}_{2}\right](\mathrm{wt} . \%>30 \%)$. In contrast, the $\mathrm{C}^{4,5}-\mathrm{H}$ and $\mathrm{C}^{2}-\mathrm{H}$ stretching frequencies were significantly blue-shifted with low concentrations of [HMIM] [NTf 2$](w t . \%<30 \%)$. Based on the experimental results (non-monotonic frequency-shift behavior) of Figure 3A, [HMIM][NTf $\left.{ }_{2}\right]$ does not seem to be homogeneously distributed within the polymeric matrix. Nanosegragation or domains of IL may exist especially for the mixtures with high concentrations of [HMIM] [NTf $\left.\mathrm{N}_{2}\right]$ (wt. $\%>30 \%$ ). The heterogeneous characteristic of ILs has attracted the attention of researchers. The non-monotonic frequency-shift behaviors revealed in Figure 3A may be related to the disturbance of inter-cluster and intra-cluster structures of ILs at high concentration and low concentration regions, respectively. The polymer may disturb the weaker inter-cluster interactions instead of the intra-cluster associations at high concentrations of [HMIM] $\left[\mathrm{NTf}_{2}\right]$ (wt. $\%>30 \%$ ). The anionic $\mathrm{v}_{\mathrm{a}} \mathrm{SO}_{2}$ absorption peak in Figure 3B did not reveal any significant frequency shift with the change in concentrations of [HMIM][NTf $\left.{ }_{2}\right]$. In conclusion, as revealed in Figure 3A, the imidazolium $\mathrm{C}^{4,5}-\mathrm{H}$ and $\mathrm{C}^{2}-\mathrm{H}$ in the ILs may be influenced by PVdF-co-HFP. Amongst these two moieties, the local structures of $\mathrm{C}^{4,5}-\mathrm{H}$ may be more easily disturbed by PVdF-co-HFP than those of the $\mathrm{C}^{2}-\mathrm{H}$ moiety. 

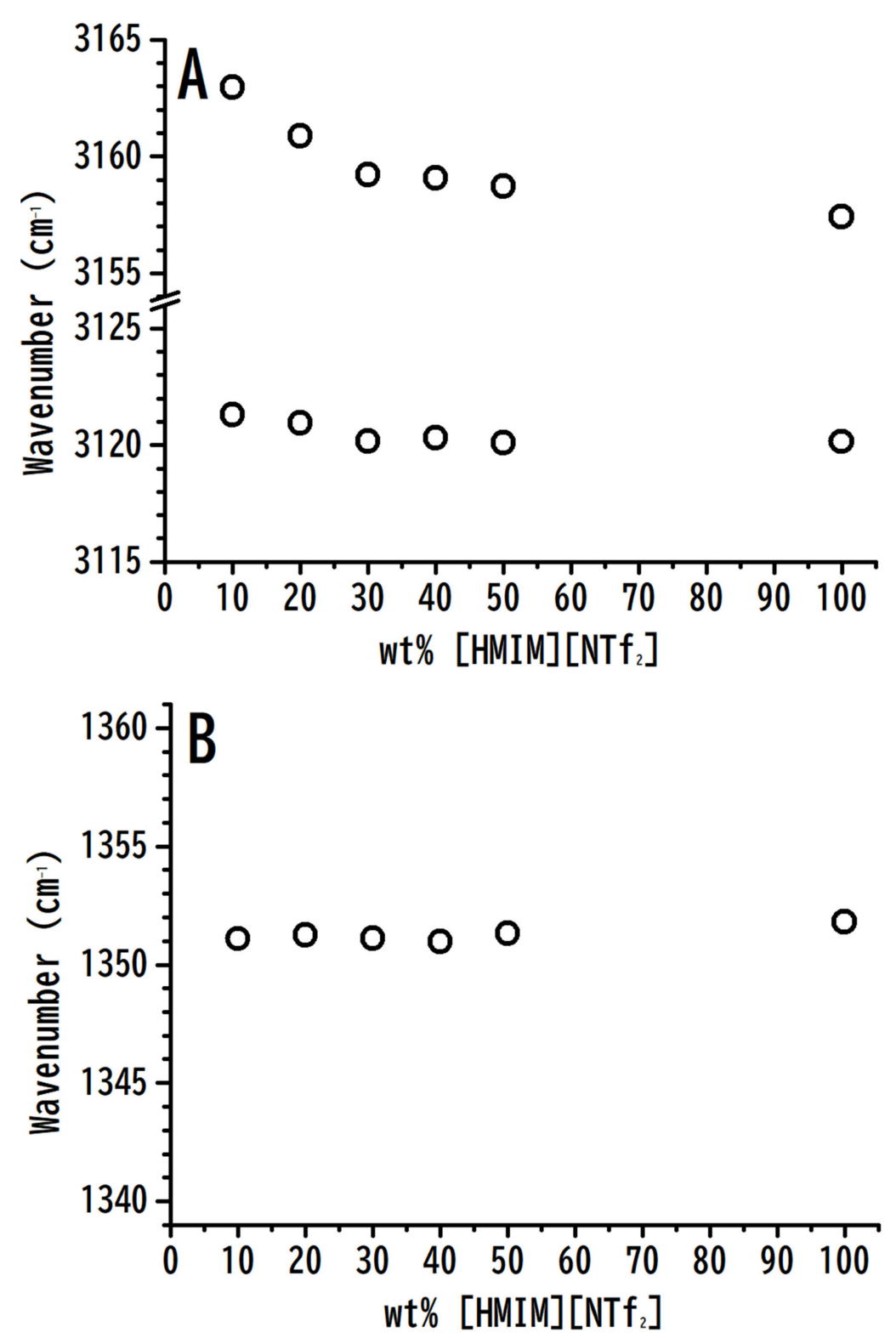

Figure 3. Concentration-dependence of the (A) imidazolium $\mathrm{C}^{4,5}-\mathrm{H}$ and $\mathrm{C}^{2}-\mathrm{H}$, and (B) anionic $\mathrm{v}_{\mathrm{a}} \mathrm{SO}_{2}$ stretching bands of [HMIM][NTf 2$] /$ PVdF-Co-HFP mixtures versus the wt. $\%$ of $[\mathrm{HMIM}]\left[\mathrm{NTf}_{2}\right]$.

\subsection{Pressure-Dependent IR Study of [HMIM][NTf2]/PVdF-co-HEP System}

Figure 4 shows the IR spectra of pure [HMIM] $\left[\mathrm{NTf}_{2}\right]$ obtained at (a) ambient pressure and (b) at pressures of $0.4,0.7,1.1,1.5,1.8$, and $2.5 \mathrm{GPa}$ in the region of $3400-2800 \mathrm{~cm}^{-1}$. On increasing the pressure from ambient condition to $0.4 \mathrm{GPa}$ (Figure $4 \mathrm{~b}$ ), the imidazolium $\mathrm{C}-\mathrm{H}$ and alkyl C-H spectral features did not reveal any notable changes. However, the peaks for the alkyl C-H and imidazolium $\mathrm{C}-\mathrm{H}$ moieties revealed a blue-shift in the frequency and a broadening of the bandwidth upon further compression (Figure $4 \mathrm{c}-\mathrm{g}$ ). For instance, the peak for imidazolium $\mathrm{C}^{4,5}-\mathrm{H}$ at $3160 \mathrm{~cm}^{-1}$ (Figure $4 \mathrm{~b}$ ) shifted to $3168 \mathrm{~cm}^{-1}$ in Figure 4c.

The IR spectra of the anionic vibrations obtained at (a) ambient pressure and (b) 0.4 , (c) 0.7 , (d) 1.1, (e) 1.5, (f) 1.8, and (g) $2.5 \mathrm{GPa}$ are displayed in Figure 5. For pure [HMIM][NTf $\left.\mathrm{NT}_{2}\right], v_{\mathrm{s}} \mathrm{SO}_{2}, v \mathrm{CF}_{3}$, and $v_{\mathrm{a}} \mathrm{SO}_{2}$ absorptions showed bandwidth changes and frequency shifts in the peaks as the pressure increased to $2.5 \mathrm{GPa}$, as shown in Figure 5. The $v_{\mathrm{a}} \mathrm{SO}_{2}$ absorption peak at $1352 \mathrm{~cm}^{-1}$ in the ambient condition was blue-shifted to $1357 \mathrm{~cm}^{-1}$ on applying a pressure of $2.5 \mathrm{GPa}$. 


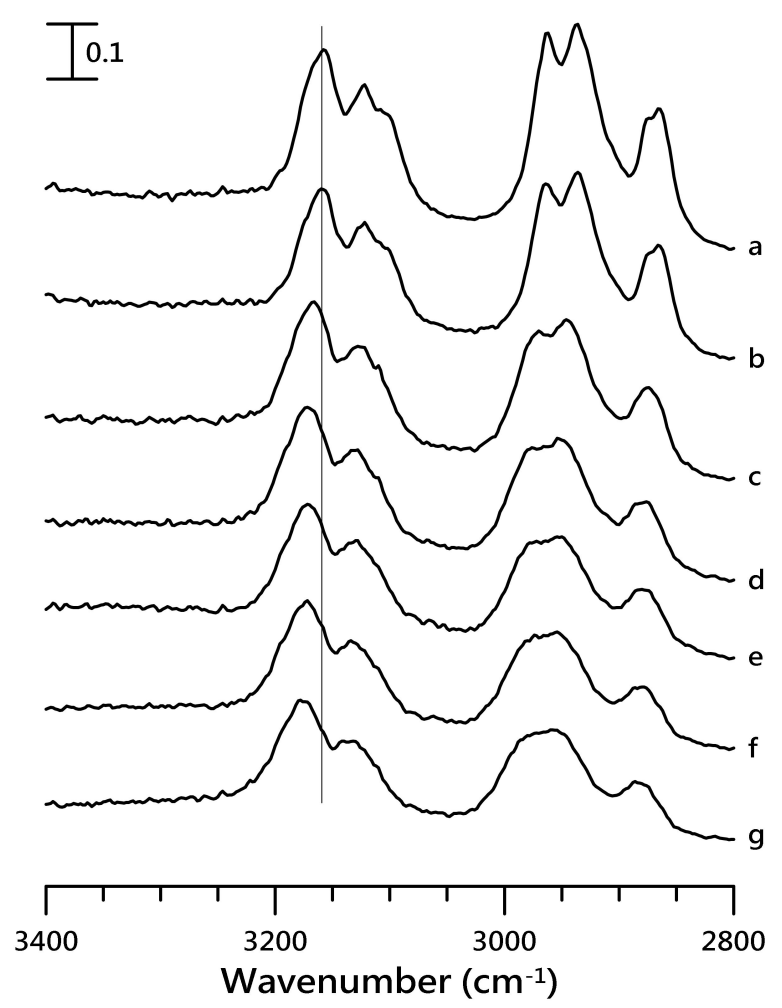

Figure 4. IR spectra of pure [HMIM] $\left[\mathrm{NTf}_{2}\right]$ obtained at (a) ambient pressure and (b) 0.4, (c) 0.7, (d) 1.1, (e) 1.5 , (f) 1.8 , and (g) $2.5 \mathrm{GPa}$.

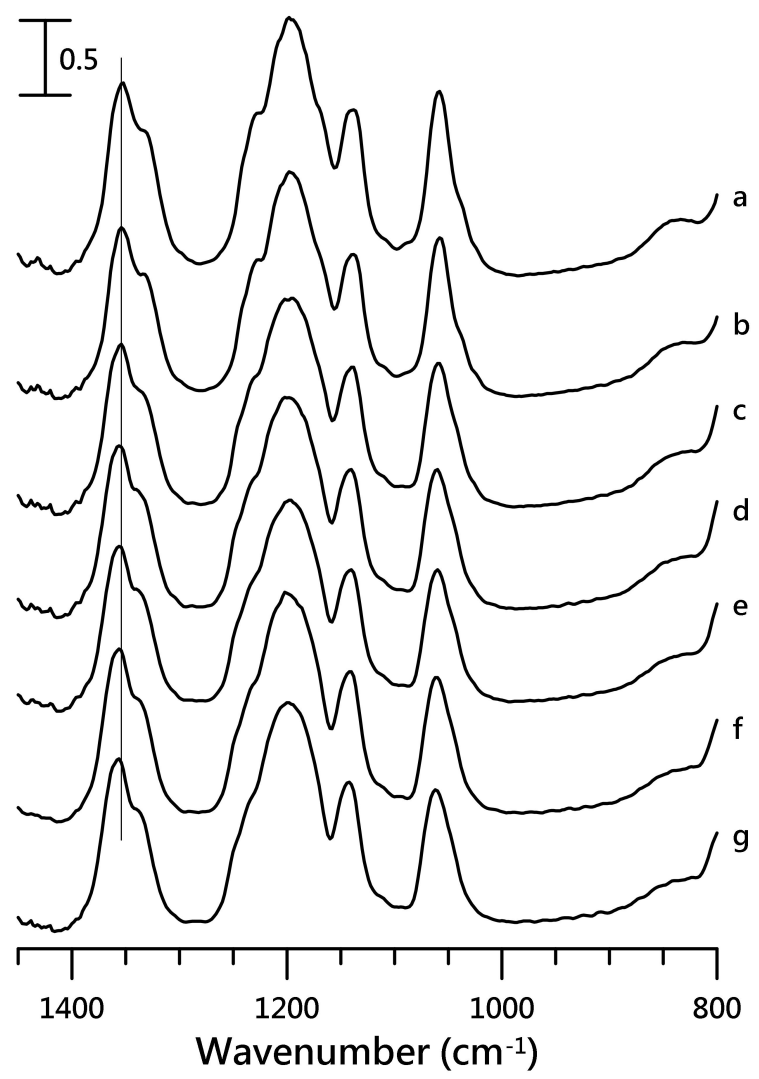

Figure 5. IR spectra of pure [HMIM] $\left[\mathrm{NTf}_{2}\right]$ obtained at (a) ambient pressure and (b) $0.4,(\mathbf{c})$ 0.7, (d) 1.1, (e) 1.5 , (f) 1.8 , and (g) $2.5 \mathrm{GPa}$. 
Figure 6 presents the IR spectra of the $[\mathrm{HMIM}]\left[\mathrm{NTF}_{2}\right] / \mathrm{PVdF}-\mathrm{co}-\mathrm{HFP}$ mixture having $10 \mathrm{wt} . \%$ of [HMIM] $\left[\mathrm{NTf}_{2}\right]$, which were recorded at (a) ambient pressure and (b) 0.4, (c) 0.7, (d) 1.1, (e) 1.5, (f) 1.8, and (g) $2.5 \mathrm{GPa}$. The alkyl C-H vibrational bands of PVdF-co-HFP (at 2979 and $3021 \mathrm{~cm}^{-1}$ ) displayed drastic blue shifts on applying a pressure $0.4 \mathrm{GPa}$ (Figure $6 \mathrm{~b}$ ) and upon further compression, the peaks exhibited small frequency shifts (Figure $6 \mathrm{c}-\mathrm{g}$ ). The cation $\mathrm{C}-\mathrm{H}$ absorption peaks were also significantly blue-shifted to 3193 and $2883 \mathrm{~cm}^{-1}$, corresponding to the imidazolium $\mathrm{C}^{4,5}-\mathrm{H}$ and alkyl C-H, respectively. IR spectra of the [HMIM][NTF 2$] / P V d F-c o-H F P$ mixture with 10 wt. $\%$ of $[\mathrm{HMIM}]\left[\mathrm{NTf}_{2}\right]$ for the $\mathrm{SO}_{2}$ stretching region are shown in Figure $\mathrm{S} 1$ in the Supplementary Materials.

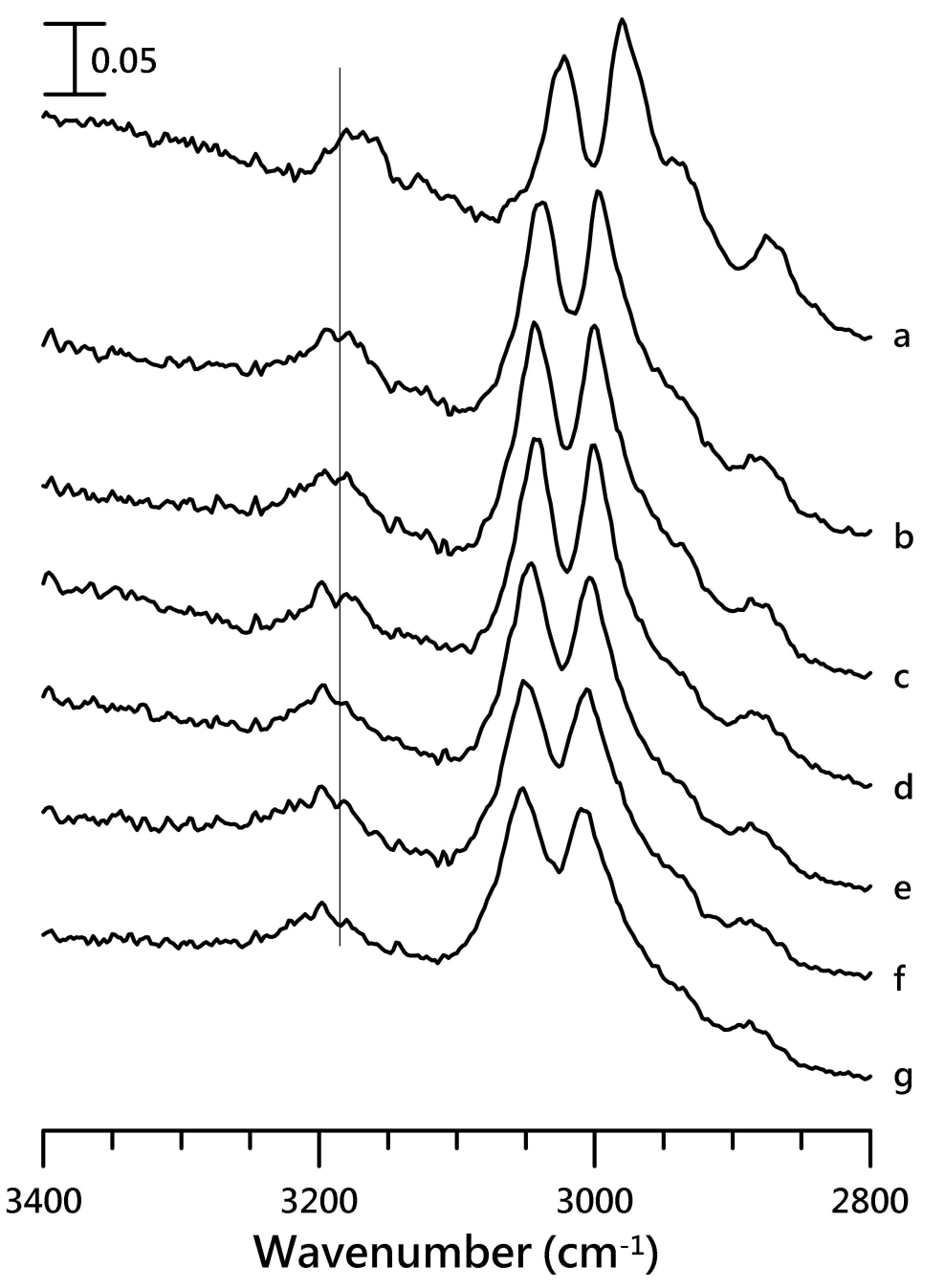

Figure 6. IR spectra of the [HMIM] $\left[\mathrm{NTF}_{2}\right] / \mathrm{PVdF}$-co-HFP mixture having $10 \mathrm{wt}$. $\%$ of [HMIM] $\left[\mathrm{NTf}_{2}\right]$, obtained at (a) ambient pressure and (b) 0.4, (c) 0.7, (d) 1.1, (e) 1.5, (f) 1.8, and (g) $2.5 \mathrm{GPa}$.

The pressure dependence of (A) imidazolium $\mathrm{C}^{4,5}-\mathrm{H}$, and (B) anionic $v_{\mathrm{a}} \mathrm{SO}_{2}$ stretching frequencies with various amounts of [HMIM][NTf $\left.\mathrm{NT}_{2}\right]$ is shown in Figure 7 . The $\mathrm{C}^{4,5}-\mathrm{H}$ band for the $[\mathrm{HMIM}]\left[\mathrm{NTf}_{2}\right] /$ PVdF-co-HFP mixtures with 10 and $50 \mathrm{wt}$ \% of [HMIM][NTf 2 displays a dramatic blue-shift (pressure-induced phase transition) of 30 and $26 \mathrm{~cm}^{-1}$, respectively, on increasing the pressure to $0.4 \mathrm{GPa}$. Subtle frequency shifts were observed in the $\mathrm{C}^{4,5}-\mathrm{H}$ band upon further compression to $2.5 \mathrm{GPa}$. The $\mathrm{C}^{4,5}-\mathrm{H}$ absorption peak for pure [HMIM] $\left[\mathrm{NTf}_{2}\right]$ showed relatively smooth blue-shifts compared to those of the mixtures, at pressures below $0.7 \mathrm{GPa}$ (Figure 7A). On increasing the pressure up to $0.7 \mathrm{GPa}$, the band was blue-shifted by $8 \mathrm{~cm}^{-1}$ in the case of pure [HMIM][NTf $\mathrm{N}_{2}$. We noticed that the frequency shifts in the $\mathrm{C}^{4,5}-\mathrm{H}$ band on varying the concentration of PVdF-co-HFP were more dramatic at high pressures (Figure 7A) than those at ambient pressure (Figure 3A). The reason for 
this might be that the local structures of $C^{4,5}-\mathrm{H}$ are significantly perturbed by the polymer under higher pressures due to pressure-enhanced IL-polymer interactions. PVdF-co-HFP may intercalate into [HMIM] $\left[\mathrm{NTf}_{2}\right]$ clusters and interact with ILs at high pressures. Figure $7 \mathrm{~B}$ indicates that the anionic $v_{\mathrm{a}} \mathrm{SO}_{2}$ stretching bands were not sensitive to the concentration variation of PVdF-co-HFP at various pressures. This suggests that the presence of PVdF-co-HFP does not disturb the local structures of the anionic $\mathrm{SO}_{2}$ groups under high pressures. Thus, the pressure-enhanced IL-polymer interactions seem to play a role in the IL-polymer systems under high pressures.
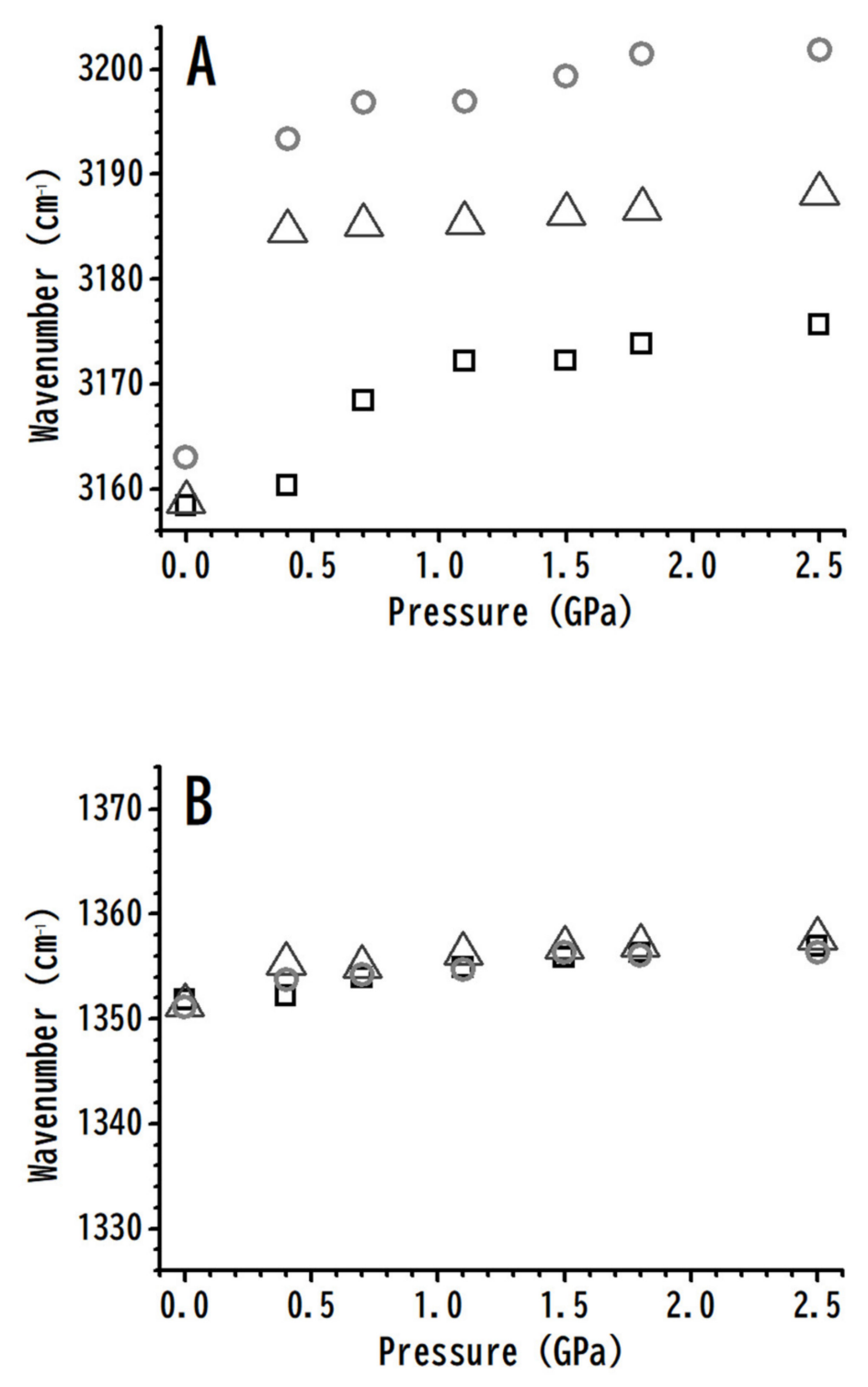

Figure 7. Pressure-dependence of the $\mathrm{C}-\mathrm{H}$ stretching frequencies for (A) imidazolium $\mathrm{C}^{4,5}-\mathrm{H}$ and (B) anionic $v_{\mathrm{a}} \mathrm{SO}_{2}$ of pure [HMIM] $\left[\mathrm{NTf}_{2}\right]$ (squares) and the $[\mathrm{HMIM}]\left[\mathrm{NTF}_{2}\right] / \mathrm{PVdF}-\mathrm{Co}-\mathrm{HFP}$ mixtures with $50 \mathrm{wt} . \%$ (triangles) and $10 \mathrm{wt} \%$ (circles) of [HMIM][NTf 2 .

\subsection{IR Study of [EMIM][NTf 2$] / P V d F-c o-H E P$ System}

To obtain a comprehensive view of the IL-polymer interactions, studies were carried out on ILs with short alkyl side chains, which is [EMIM] $\left[\mathrm{NTf}_{2}\right]$. The IR spectrum with the cationic absorption of pure [EMIM][NTf $\left.{ }_{2}\right]$ was obtained at (a) ambient pressure and (b) 0.4, (c) 0.7, (d) 1.1, (e) 1.5, (f) 1.8, and (g) 2.5 GPa (Figure 8). 


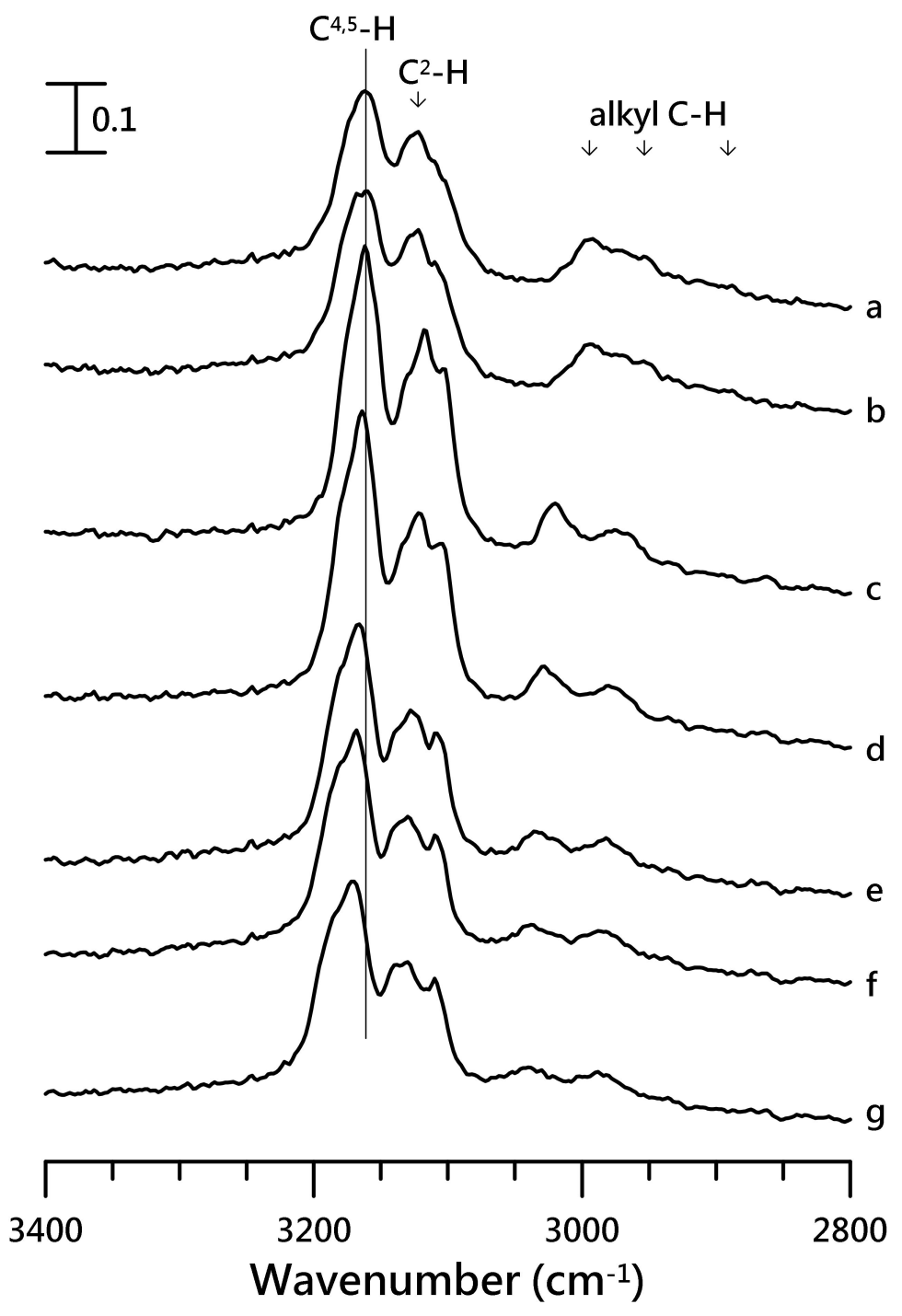

Figure 8. IR spectra of pure [EMIM] $\left[\mathrm{NTf}_{2}\right]$ obtained at (a) ambient pressure and (b) 0.4, (c) 0.7, (d) 1.1, (e) 1.5 , (f) 1.8 , and (g) $2.5 \mathrm{GPa}$.

The $\mathrm{C}^{4,5}-\mathrm{H}$ peak of [EMIM][NTf 2 at $3161 \mathrm{~cm}^{-1}$, obtained at ambient pressure, was blue-shifted to $3175 \mathrm{~cm}^{-1}$ on increasing the pressure to $2.5 \mathrm{GPa}$ (Figure $8 \mathrm{~g}$ ). The $\mathrm{C}^{4,5}-\mathrm{H}$ and $\mathrm{C}^{2}-\mathrm{H}$ absorptions in Figure 8 revealed the changes in spectral features with pressure. Based on the results shown in Figure 8 , it can be speculated that pressure may interfere with the cluster association of [EMIM] $\left[\mathrm{NTf}_{2}\right]$. The pressure-induced phase transition or solidification may likely take place at a pressure of $<0.7 \mathrm{GPa}$ (see Figure $8 \mathrm{c}$ ) for pure [EMIM][NTf 2 . The peak narrowing observed at high pressures $(p>0.7 \mathrm{GPa})$ may suggest the formation of ordered structures. Different solidification pressures of ionic liquids for IR and Raman measurements have been reported in the literature $[22,37,38]$ The different solidification pressures may originate from the various amounts of water in ILs [39] and the different experimental configurations inherent to IR and Raman techniques. It is instructive to note that the presence of water in ILs may significantly influence the overall phase behaviors. For the high-pressure IR measurements, $\mathrm{Ca}_{2} \mathrm{~F}$ crystals were placed into the sample holder to avoid power saturation of the ionic liquid's IR band. The $\mathrm{CaF}_{2}$ grains likely provide numerous nucleation sites that enable solidification of the ionic liquid. The addition of $\mathrm{CaF}_{2}$ is not required for high-pressure Raman measurements, and the ionic liquid is in contact with the smooth diamond surface, which present fewer nucleation sites. Thus, the phase transformation is accompanied by some degree of hysteresis in the Raman data, with the crystalline form persisting to pressures <1 GPa during decompression [38]. 
The $\mathrm{C}^{4,5}-\mathrm{H}$ and $v_{\mathrm{a}} \mathrm{SO}_{2}$ stretching frequencies of [EMIM][NTf 2$] / \mathrm{PVdF}-\mathrm{Co}-\mathrm{HFP}$ mixtures with 10 , $50 \mathrm{wt} . \%$ of $[\mathrm{EMIM}]\left[\mathrm{NTf}_{2}\right]$, and pure $[\mathrm{EMIM}]\left[\mathrm{NTf}_{2}\right]$ under various pressures are shown in Figure 9.
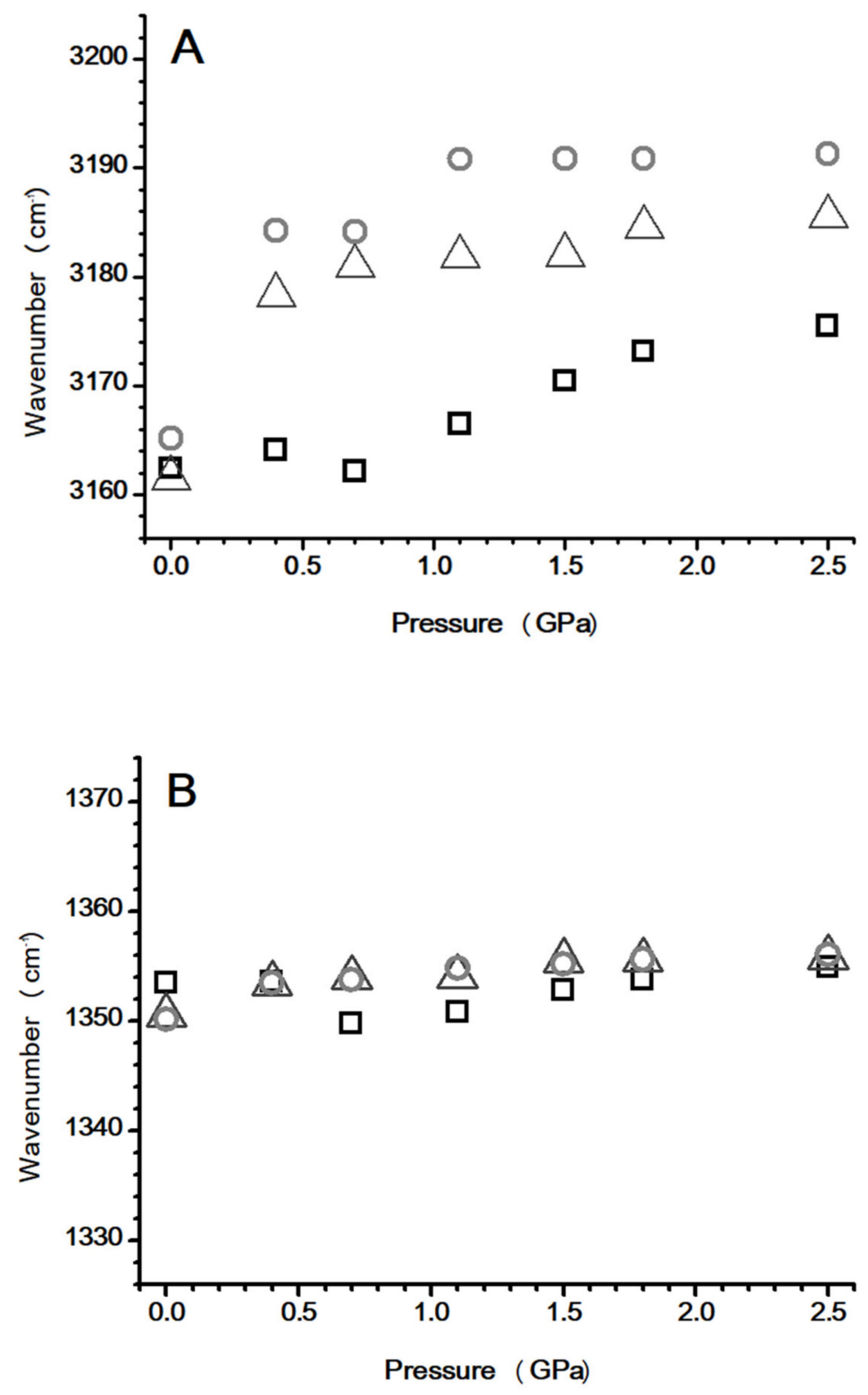

Figure 9. Pressure dependence of the $\mathrm{C}-\mathrm{H}$ stretching frequencies for $(\mathbf{A})$ imidazolium $\mathrm{C}^{4,5}-\mathrm{H}$ and $(\mathbf{B})$ anionic $v_{\mathrm{a}} \mathrm{SO}_{2}$ of pure [EMIM][NTf ${ }_{2}$ (squares) and the [EMIM][NTF 2$] / \mathrm{PVdF}$-co-HFP mixtures with $50 \mathrm{wt} . \%$ (triangles) and $10 \mathrm{wt} . \%$ (circles) of [EMIM][NTf 2 ].

The $\mathrm{C}^{4,5}-\mathrm{H}$ band of pure [EMIM][NTf $\mathrm{N}_{2}$ (Figure 9A) was blue-shifted on increasing the pressure from ambient condition to $0.4 \mathrm{GPa}$. The peak only slightly shifted on further increasing the pressure to $2.5 \mathrm{GPa}$. The $\mathrm{C}^{4,5}-\mathrm{H}$ absorption of [EMIM][NTf $\left.\mathrm{N}_{2}\right] / \mathrm{PVdF}-\mathrm{co}-\mathrm{HFP}$ mixtures with 50 and $10 \mathrm{wt} . \%$ of [EMIM][NTf $f_{2}$ also showed blue-shifts on increasing the pressure from ambient condition to $0.4 \mathrm{GPa}$. As shown in Figure 9A, the $\mathrm{C}^{4,5}-\mathrm{H}$ absorption band of pure [EMIM] $\left[\mathrm{NTf}_{2}\right]$ at $3161 \mathrm{~cm}^{-1}$ was slightly blue-shifted to $3165 \mathrm{~cm}^{-1}$ for the $10 \mathrm{wt} . \%$ mixture at ambient condition. Under a pressure of $2.5 \mathrm{GPa}$, the $\mathrm{C}^{4,5}-\mathrm{H}$ band was located at $3177 \mathrm{~cm}^{-1}$ and $3191 \mathrm{~cm}^{-1}$ for pure [EMIM] [NTf 2 ] and the $10 \mathrm{wt} . \%$ mixture, respectively. Hence, the frequency shifts $(v(10 \mathrm{wt} . \%)-v($ pure $))$ caused by the presence of PVdF-co-HFP increased from $4 \mathrm{~cm}^{-1}$ at ambient pressure to $14 \mathrm{~cm}^{-1}$ at $2.5 \mathrm{GPa}$. It may be possible that PVdF-co-HFP interjects into the IL cluster via pressure-enhanced IL-polymer interactions under high 
pressures. We note that the blue shifts due to the addition of PVdF-co-HFP under high pressures were more obvious for the [HMIM][NTf $\left.{ }_{2}\right]$ mixtures (Figure $7 \mathrm{~A}$ ) than those for the [EMIM] $\left[\mathrm{NTf}_{2}\right]$ mixtures (Figure 9A). These results indicate that the length of the alkyl side chain plays an appreciable role in the IL-PVdF-co-HFP interactions. As shown in Figure 9, the pressure-dependent anionic $v_{\mathrm{a}} \mathrm{SO}_{2}$ stretching frequencies were almost identical for the various concentrations of PVdF-co-HFP. The IR spectra of the [EMIM] $\left[\mathrm{NTF}_{2}\right] / \mathrm{PVdF}-\mathrm{Co}-\mathrm{HFP}$ mixture with $10 \mathrm{wt} . \%$ of $[\mathrm{HMIM}]\left[\mathrm{NTf}_{2}\right]$ for the $\mathrm{SO}_{2}$ stretching region are shown in Figure S2 in the Supplementary Materials. The presence of polymers may not interfere with the anionic $\mathrm{SO}_{2}$ local structures under high pressures, as shown in Figure 9B, and Figure 7B for [EMIM] $\left[\mathrm{NTf}_{2}\right]$ and [HMIM] $\left[\mathrm{NTF}_{2}\right]$, respectively. By the way, the reversibility of IR spectra upon pressure-cycling was checked (see Figure S3 in the Supplementary Materials). In order to check that there were no obvious hysteretic behaviors, IR spectra with time under the pressure of $0.7 \mathrm{GPa}$ were measured and are displayed in Figure S4 in the Supplementary Materials. To reduce the influence of water content [39] in this study, pressure-dependent IR spectra of pre-heated [EMIM][ $\mathrm{NTf}_{2}$ ] (up to $155^{\circ} \mathrm{C}$ ) were obtained and are shown in Figure S5 in the Supplementary Materials.

Figure 10 is a schematic illustration of the possible interactions between [HMIM] $\left[\mathrm{NTf}_{2}\right]$ and PVdF-co-HFP in the[HMIM][NTf 2 ]-PVdF-co-HFP mixtures, The addition of PVdF-co-HFP may produce the interactions such as the $\mathrm{C}^{4,5}-\mathrm{H}-\mathrm{PVdF}-\mathrm{co}-\mathrm{HFP}$ associations, while the local structures of the $\mathrm{C}^{2}-\mathrm{H}$ and anionic $\mathrm{SO}_{2}$ groups revealed remarkably less changes. Pressures used in this study ranged from ambient to several GPa; such pressures mainly change intermolecular distances and affect conformations. In fact, pressures in excess of $30 \mathrm{GPa}$ are required to change the electronic structure of a molecule. In this study, we show that high pressure is a sensitive method to investigate how the local structure responds to pressure variation.

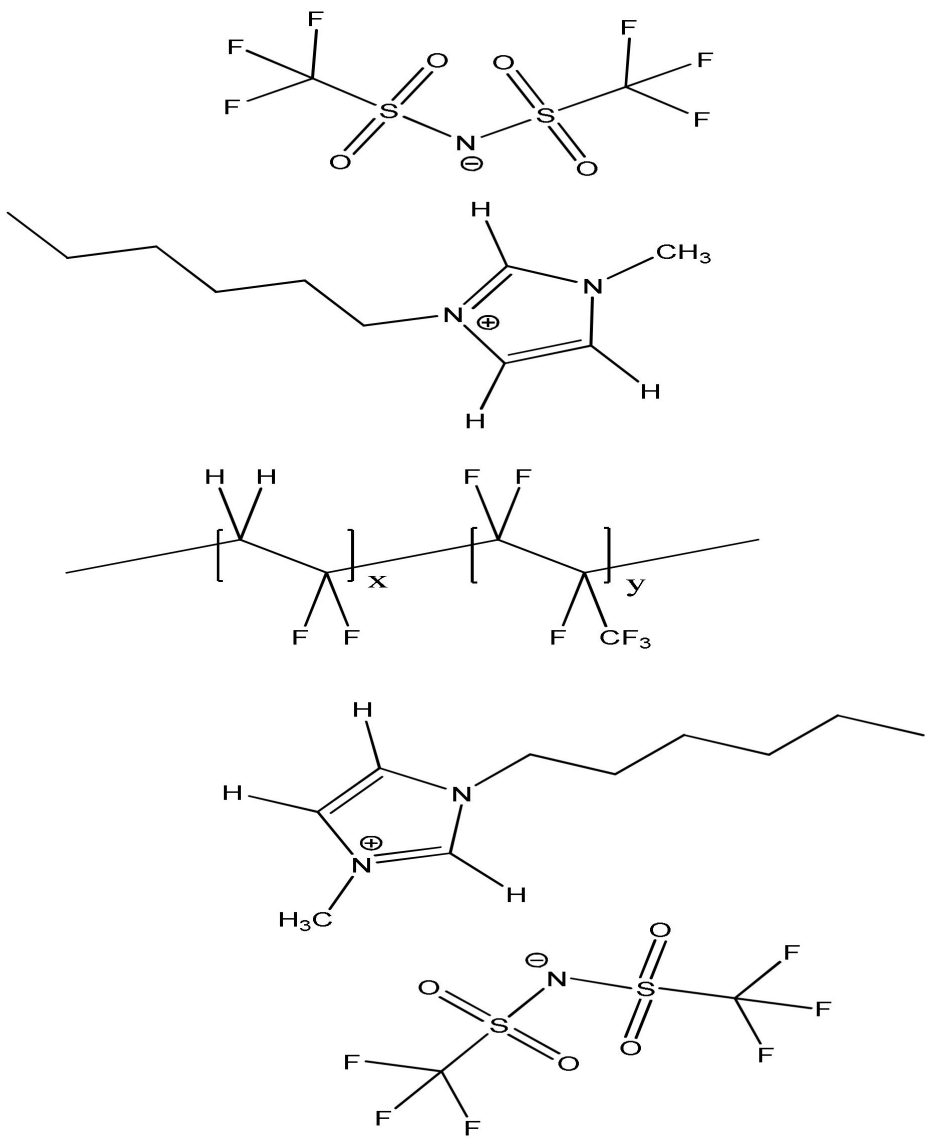

Figure 10. Illustration of the possible $[\mathrm{HMIM}]\left[\mathrm{NTf}_{2}\right]-\mathrm{PVdF}-\mathrm{Co}-\mathrm{HFP}$ structures in the mixtures. 


\section{Conclusions}

In this study, the local nanostructures of imidazolium IL-PVdF-co-HFP mixtures were investigated by using high-pressure infrared spectroscopy. The imidazolium $\mathrm{C}^{4,5}-\mathrm{H}$ vibration was blue-shifted non-monotonically on mixing the IL with PVdF-co-HFP under ambient pressure. The $\mathrm{C}^{4,5}-\mathrm{H}$ absorptions of the mixtures exhibited dramatic blue-shifts on increasing the pressure to values higher than $0.4 \mathrm{GPa}$. The results indicated that the local structures of imidazolium $\mathrm{C}^{4,5}-\mathrm{H}$ were significantly disturbed by the pressure-enhanced $\mathrm{C}^{4,5}-\mathrm{H}$-polymer interactions. Nevertheless, the anionic $v_{\mathrm{a}} \mathrm{SO}_{2}$ absorption frequencies were almost identical for various pressures. The local structures of the anionic $\mathrm{SO}_{2}$ groups were not disturbed under high pressures. Due to the overlapping of absorptions from PVdF-co-HFP, the peaks from $\left[\mathrm{NTf}_{2}\right]$ that we were able to identify and analyze were limited $\left(\right.$ only $\left.\mathrm{SO}_{2}\right)$. Thus, complementary techniques are needed to study the interactions and the role of the anions of these ILs in the IL/PVdF-co-HFP mixtures This study suggests that pressure-enhance IL-polymer interactions play a prominent role under high pressures.

Supplementary Materials: The following are available online at http://www.mdpi.com/2079-4991/10/10/1973/s1, Figure S1: IR spectra of the $[\mathrm{HMIM}]\left[\mathrm{NTF}_{2}\right] / \mathrm{PVdF}-\mathrm{Co}-\mathrm{HFP}$ mixture featuring $10 \mathrm{wt} . \%$ of $[\mathrm{HMIM}]\left[\mathrm{NTf}_{2}\right]$ obtained at (a) ambient pressure and (b) 0.4, (c) 0.7, (d) 1.1, (e) 1.5, (f) 1.8, and (g) 2.5 GPa, Figure S2: IR spectra of the [EMIM][NTF2]/PVdF-co-HFP mixture featuring $10 \mathrm{wt} . \%$ of [EMIM][NTf2] obtained at (a) ambient pressure and (b) 0.4, (c) 0.7, (d) 1.1, (e) 1.5, (f) 1.8, and (g) $2.5 \mathrm{GPa}$, Figure S3: IR spectra of the [HMIM][NTF 2$] /$ PVdF-co-HFP mixture featuring $50 \mathrm{wt} . \%$ of $[\mathrm{HMIM}]\left[\mathrm{NTf}_{2}\right]$ obtained at (a) ambient pressure, (b) $2.5 \mathrm{GPa}$, and (c) cycle back to ambient pressure, Figure S4: IR spectra of pure [EMIM][NTf 2 ] obtained at the time of (a) $5 \mathrm{~min}$ (100 scans), (b) $1 \mathrm{~h}$ (1000 scans), (c) $2 \mathrm{~h}$ (1000 scans), and (d) $3 \mathrm{~h}$ (1000 scans) after the compression under the pressure of $0.7 \mathrm{GPa}$, Figure S5: IR spectra of pure [EMIM] $\left[\mathrm{NTf}_{2}\right]$ (pre-heated to $155^{\circ} \mathrm{C}$ ) obtained at (a) ambient pressure and (b) 0.4 , (c) 0.7 , (d) 1.1 , (e) 1.5, (f) 1.8 , and (g) $2.5 \mathrm{GPa}$ at $25^{\circ} \mathrm{C}$.

Author Contributions: Formal analysis, T.-H.W.; Data curation, M.-S.W.; Writing-original draft preparation, T.-H.W.; Writing-review and editing, H.-C.C.; Supervision, H.-C.C. All authors have read and agreed to the published version of the manuscript.

Funding: This research was funded by Ministry of Science and Technology (Contract No. MOST 108-2113-M-259-005) of Taiwan.

Acknowledgments: The authors thank the National Dong Hwa University and Ministry of Science and Technology (Contract No. MOST 108-2113-M-259-005) of Taiwan for financial support. The authors thank Kang-Yu Hsiao and Yen-Wen Chiou for the assistance.

Conflicts of Interest: The authors declare no conflict of interest.

\section{References}

1. Francis, C.F.; Kyratzis, I.L.; Best, A.S. Lithium-Ion Battery Separators for Ionic-Liquid Electrolytes: A Review. Adv. Mater. 2020, 32, 1904205. [CrossRef] [PubMed]

2. Yadav, N.; Mishra, K.; Hashmi, S. Nanofiller-incorporated porous polymer electrolyte for electrochemical energy storage devices. High Perform. Polym. 2018, 30, 957-970. [CrossRef]

3. McGrath, L.M.; Jones, J.; Carey, E.; Rohan, J.F. Ionic Liquid Based Polymer Gel Electrolytes for Use with Germanium Thin Film Anodes in Lithium Ion Batteries. ChemistryOpen 2019, 8, 1429-1436. [CrossRef] [PubMed]

4. Lagadec, M.F.; Zahn, R.; Wood, V. Characterization and performance evaluation of lithium-ion battery separators. Nat. Energy 2019, 4, 16-25. [CrossRef]

5. Dutta, B.; Deb, D.; Bhattacharya, S. Electroactive phase nucleation and isothermal crystallization kinetics in ionic liquid-functionalized ZnS nanoparticle-ingrained P (VDF-HFP) copolymer nanocomposites. J. Mater. Sci. 2019, 54, 2990-3008. [CrossRef]

6. Tuhania, P.; Singh, P.K.; Bhattacharya, B.; Dhapola, P.S.; Yadav, S.; Shukla, P.; Gupta, M. PVDF-HFP and 1-ethyl-3-methylimidazolium thiocyanate-doped polymer electrolyte for efficient supercapacitors. High Perform. Polym. 2018, 30, 911-917. [CrossRef]

7. Wang, J.; Luo, J.; Feng, S.; Li, H.; Wan, Y.; Zhang, X. Recent development of ionic liquid membranes. Green Energy Environ. 2016, 1, 43-61. [CrossRef] 
8. Wang, X.; Xiao, C.; Liu, H.; Huang, Q.; Hao, J.; Fu, H. Poly (vinylidene fluoride-hexafluoropropylene) porous membrane with controllable structure and applications in efficient oil/water separation. Materials 2018, 11, 443. [CrossRef]

9. Sasikumar, M.; Jagadeesan, A.; Raja, M.; Krishna, R.H.; Sivakumar, P. The effects of PVAc on surface morphological and electrochemical performance of $\mathrm{P}$ (VdF-HFP)-based blend solid polymer electrolytes for lithium ion-battery applications. Ionics 2019, 25, 2171-2181. [CrossRef]

10. Correia, D.M.; Costa, C.M.; Lizundia, E.; Sabater i Serra, R.; Gómez-Tejedor, J.A.; Biosca, L.T.; Meseguer-Dueñas, J.M.; Gomez Ribelles, J.L.; Lanceros-Méndez, S. Influence of cation and anion type on the formation of the electroactive $\beta$-phase and thermal and dynamic mechanical properties of poly (vinylidene fluoride)/ionic liquids blends. J. Phys. Chem. C 2019, 123, 27917-27926. [CrossRef]

11. Das, S.; Ghosh, A. Symmetric electric double-layer capacitor containing imidazolium ionic liquid-based solid polymer electrolyte: Effect of $\mathrm{TiO}_{2}$ and $\mathrm{ZnO}$ nanoparticles on electrochemical behavior. J. Appl. Polym. Sci. 2020, 137, 48757. [CrossRef]

12. Luo, R.; Li, Q.; Du, B.; Zhou, S.; Chen, Y. Preparation and characterization of solid electrolyte doped with carbon nanotubes and its preliminary application in $\mathrm{NO}_{2}$ gas sensors. Front. Mater. 2019, 6, 113. [CrossRef]

13. Thomas, M.; Rajiv, S. Dye-sensitized solar cells based on an electrospun polymer nanocomposite membrane as electrolyte. New J. Chem. 2019, 43, 4444-4454. [CrossRef]

14. Wasserscheid, P.; Welton, T. Ionic Liquids in Synthesis; Wiley-VCH: Weinheim, Germany, 2008; pp. 1-367.

15. Roth, C.; Chatzipapadopoulos, S.; Kerlé, D.; Friedriszik, F.; Lütgens, M.; Lochbrunner, S.; Kühn, O.; Ludwig, R. Hydrogen bonding in ionic liquids probed by linear and nonlinear vibrational spectroscopy. New J. Phys. 2012, 14, 105026. [CrossRef]

16. Hayes, R.; Warr, G.G.; Atkin, R. Structure and nanostructure in ionic liquids. Chem. Rev. 2015, 115, 6357-6426. [CrossRef]

17. Sosa, J.E.; Malheiro, C.; Ribeiro, R.P.; Castro, P.J.; Piñeiro, M.M.; Araújo, J.M.; Plantier, F.; Mota, J.P.; Pereiro, A.B. Adsorption of fluorinated greenhouse gases on activated carbons: Evaluation of their potential for gas separation. J. Chem. Technol. Biotechnol. 2020, 95, 1892-1905. [CrossRef]

18. Welton, T. Ionic liquids: A brief history. Biophys. Rev. 2018, 10, 691-706. [CrossRef]

19. Luís, A.; Shimizu, K.; Araújo, J.M.; Carvalho, P.J.; Lopes-da-Silva, J.A.; Canongia Lopes, J.N.; Rebelo, L.P.N.; Coutinho, J.A.; Freire, M.G.; Pereiro, A.B. Influence of nanosegregation on the surface tension of fluorinated ionic liquids. Langmuir 2016, 32, 6130-6139. [CrossRef]

20. Shimizu, K.; Bernardes, C.E.S.; Canongia Lopes, J.N. Structure and Aggregation in the 1-Alkyl-3-Methylimidazolium Bis(trifluoromethylsulfonyl)imide Ionic Liquid Homologous Series. J. Phys. Chem. B 2014, 118, 567-576. [CrossRef]

21. Dutta, R.; Kundu, S.; Sarkar, N. Ionic liquid-induced aggregate formation and their applications. Biophys. Rev. 2018, 10, 861-871. [CrossRef]

22. Burba, C.M.; Chang, H.-C. Temperature-and pressure-dependent infrared spectroscopy of 1-butyl-3methylimidazolium trifluoromethanesulfonate: A dipolar coupling theory analysis. Spectrochim. Acta A 2018, 193, 338-343. [CrossRef] [PubMed]

23. Chaurasia, S.; Singh, R.; Chandra, S. Thermal stability, complexing behavior, and ionic transport of polymeric gel membranes based on polymer PVdF-HFP and ionic liquid, [BMIM][BF4]. J. Phys. Chem. B 2013, 117, 897-906.

24. Liang, C.-L.; Mai, Z.-H.; Xie, Q.; Bao, R.-Y.; Yang, W.; Xie, B.-H.; Yang, M.-B. Induced formation of dominating polar phases of poly (vinylidene fluoride): Positive ion- $\mathrm{CF}_{2}$ dipole or negative ion- $\mathrm{CH}_{2}$ dipole interaction. J. Phys. Chem. B 2014, 118, 9104-9111. [CrossRef] [PubMed]

25. Sarkar, R.; Kundu, T. Density functional theory studies on PVDF/ionic liquid composite systems. J. Chem. Sci. 2018, 130, 115. [CrossRef]

26. Jansen, J.C.; Clarizia, G.; Bernardo, P.; Bazzarelli, F.; Friess, K.; Randová, A.; Schauer, J.; Kubicka, D.; Kacirková, M.; Izak, P. Gas transport properties and pervaporation performance of fluoropolymer gel membranes based on pure and mixed ionic liquids. Sep. Purif. Technol. 2013, 109, 87-97. [CrossRef]

27. Wang, T.-H.; Shen, M.-H.; Chang, H.-C. Pressure-Dependent Stability of Imidazolium-Based Ionic Liquid/DNA Materials Investigated by High-Pressure Infrared Spectroscopy. Materials 2019, 12, 4202. [CrossRef]

28. Wang, T.-H.; Lin, E.-Y.; Chang, H.-C. Pressure-Dependent Confinement Effect of Ionic Liquids in Porous Silica. Nanomaterials 2019, 9, 620. [CrossRef] 
29. Wang, T.-H.; Hong, S.-Y.; Chang, H.-C. The validity of high pressure IR for detecting the interactions between $\beta$-cyclodextrin and imidazolium based ionic liquids. AIP Adv. 2019, 9, 075007. [CrossRef]

30. Chang, H.-C.; Wang, T.-H.; Burba, C.M. Probing structures of interfacial 1-butyl-3-methylimidazolium trifluoromethanesulfonate ionic liquid on nano-aluminum oxide surfaces using high-pressure infrared spectroscopy. Appl. Sci. 2017, 7, 855. [CrossRef]

31. Chang, Y.-H.; Chang, H.-C.; Fu, Y.-P. Utilizing infrared spectroscopy to analyze the interfacial structures of ionic liquids/Al2O3 and ionic liquids/mica mixtures under high pressures. Nanomaterials 2019, 9, 373. [CrossRef]

32. Wong, P.; Moffatt, D.; Baudais, F. Crystalline quartz as an internal pressure calibrant for high-pressure infrared spectroscopy. Appl. Spectrosc. 1985, 39, 733-735. [CrossRef]

33. Wong, P.; Moffatt, D. The uncoupled OH or OD stretch in water as an internal pressure gauge for high-pressure infrared spectroscopy of aqueous systems. Appl. Spectrosc. 1987, 41, 1070-1072. [CrossRef]

34. Daneshkhah, A.; Shrestha, S.; Siegel, A.; Varahramyan, K.; Agarwal, M. Cross-selectivity enhancement of poly (vinylidene fluoride-hexafluoropropylene)-based sensor arrays for detecting acetone and ethanol. Sensors 2017, 17, 595. [CrossRef] [PubMed]

35. Hanke, K.; Kaufmann, M.; Schwaab, G.; Havenith, M.; Wolke, C.T.; Gorlova, O.; Johnson, M.A.; Kar, B.P.; Sander, W.; Sanchez-Garcia, E. Understanding the ionic liquid [NC 4111][NTf 2] from individual building blocks: An IR-spectroscopic study. Phys. Chem. Chem. Phys. 2015, 17, 8518-8529. [CrossRef] [PubMed]

36. Lahiri, A.; Borisenko, N.; Borodin, A.; Olschewski, M.; Endres, F. Characterisation of the solid electrolyte interface during lithiation/delithiation of germanium in an ionic liquid. Phys. Chem. Chem. Phys. 2016, 18, 5630-5637. [CrossRef] [PubMed]

37. Ribeiro, M.C.C.; Padua, A.A.H.; Costa Gomes, M.F. Glass transition of ionic liquids under high pressure. J. Chem. Phys. 2014, 140, 244514. [CrossRef]

38. Faria, L.F.O.; Ribeiro, M.C.C. Phase transitions of triflate-based ionic liquids under high pressure. J. Phys. Chem. B 2015, 119, 14315-14322. [CrossRef]

39. Freire, M.G.; Santos, L.M.N.B.F.; Fernandes, A.M.; Coutinho, J.A.P.; Marrucho, I.M. An overview of the mutual solubilities of water-imidazolium-based ionic liquids systems. Fluid Phase Equilib. 2007, 261, 449-454. [CrossRef]

(C) 2020 by the authors. Licensee MDPI, Basel, Switzerland. This article is an open access article distributed under the terms and conditions of the Creative Commons Attribution (CC BY) license (http://creativecommons.org/licenses/by/4.0/). 